\title{
To the Reader,
}

This issue of Central European Geology contains papers describing presentations of the 11th Isotope Workshop of the European Society for Isotope Research held in Budapest. Conference volumes of earlier workshops contained usually abstracts or extended abstracts. However, several participants sent inquiries if longer papers could be published beside the usual conference abstracts. The organizers and the editors decided to provide the possibility of publication of short and regular papers. Some of the submitted manuscripts were not presented at the meeting, but all of them were related to isotope research. Thus, the publishers and the editors decided to insert these papers in the special issue after the regular review process and merge two issues in a double one in order to produce a coherent compilation of papers.

The compilation of the issue was mainly conducted by the guest editor and president of the Society, István Forizs, with the help of the local organizing team. The team had a hard job to arrange reviewing, pursue authors to revise the papers and edit the final versions, so their work is gratefully thanked. Finally I would like to express my gratitude to the reviewers. The special issue greatly benefitted from their help as they provided their opinions in very short course. I hope the readers will like the issue and find interesting ideas in the papers, and if they do, the investment of the authors, the organizers and the reviewers will pay off.

Kind regards,

Attila Demény Editor-in-Chief

\section{Introduction}

It was in 1991 when late István Cornides, the father of isotope geochemistry in Hungary, gave us a printed invitation for an Isotope Workshop to be held in Lublin in May 1992. Our stable isotope laboratory was established just in the preceding year, we were two years after the political turnover in the Eastern European Block, and we were young, so in 1992 with a great enthusiasm together with my colleague Attila Demény (now director of our institute) we drove happily to Lublin, Poland. And our expectations were more than fulfilled. We could make fruitful contacts with well-known researchers and good friendships. We were so enthusiastic that we decided to establish an international society. And we did it under the name International Isotope Society registered in Poland. Soon I noticed that there was another society with exactly the same name. Although they offered the fusion of these two societies, we wanted to go on our way; therefore in 1996 we changed the name to European Society for Isotope Research (ESIR). Our intention was to organize biannual meetings in Europe, mostly in Central Europe providing an opportunity for researchers living in the former 
communist countries to come together on moderate costs and to meet colleagues living in other part of Europe and of the world.

Anyway, the 'Isotope Workshop I' held in 1992 in Lublin was a starting point of a series of workshops with slightly increasing number of attendees and firmly developing in quality. Let's recall the venues and organizers of these workshops: 1st in Lublin, Poland, 1992 (Mariusz-Orion Jędrysek, Stanislaw Halas); 2nd in Ksiaz, Poland, 1994 (Mariusz-Orion Jędrysek); 3rd in Budapest, Hungary, 1996 (Attila Demény, István Fórizs); 4th in Portorož, Slovenia, 1998 (Jože Pezdic); 5th in Cracow, Poland, 2000 (Przemislaw Wachniew); 6th in Tallinn, Estonia, 2002 (Rein Vaikmäe); 7th in Seggauberg, Austria, 2004 (Ana-Voica Bojar); 8th in Leipzig, Germany, 2005 (Gerhard Strauch); 9th in Cluj, Romania, 2007 (Bogdan P. Onac); 10th in Zlotniki Lubanskie, Poland, 2009 (Adriana Trojanowska); and now the 11th in Budapest, Hungary, 2011 (István Fórizs).

This time the number of registered participants is 95 - the biggest so far indicating the success of previous Isotope Workshops and the increasing need for the research dealing with environmental isotopes. The meeting is based on 50 oral and 44 poster presentations with a wide range of scopes, including two invited speakers and seven key note lecturers. Reflecting the modern trends the two invited speakers present review papers on paleoclimate: "Isotopic memory of fossils" (Christophe Lécuyer) and "Semi-continuous online isotope and elemental ratio measurements of high time resolution on Greenland ice cores for temperature reconstruction" (Markus Leuenberger). The presentations are arranged into seven chapters (Biogeochemistry, Environmental Geochemistry and Ecology, General Isotope Geochemistry, Inert Gas and Radiogenic Isotopes, Isotope Hydrology, Paleoclimate, Technical Developments), among which the section of Isotope Hydrology is the biggest one with 27 presentations underlining the growing importance of water research.

I wish a joyful time for the readers while reading this Volume.

István Fórizs

Guest Editor

President of the European Society for Isotope Research Senior research fellow, Institute for Geochemical Research, Hungarian Academy of Sciences 